\title{
MANAGEMENT OF HAEMORRHOIDS BY OPEN AND CLOSED HAEMORRHOIDECTOMY- A COMPARATIVE STUDY
}

\author{
Bikash Sandalya ${ }^{1}$
}

${ }_{1}^{1}$ Assistant Professor, Department of General Surgery, Silchar Medical College and Hospital.

ABSTRACT

\section{BACKGROUND}

Haemorrhoids are estimated to affect nearly $40 \%$ of the population during their lifetime in some form or the other. Milder forms respond to conservative management whereas surgical approach is necessary in the others. Different surgical methods have their pros and cons, and therefore the method opted should be individualised.

Aim- To compare the outcome of open and closed haemorrhoidectomy in second, third and fourth degree haemorrhoids.

\section{MATERIALS AND METHODS}

This prospective, comparative clinical trial was conducted in the Department of General Surgery, Silchar Medical College and Hospital from August 2016 to July 2017. 30 patients with $2^{\text {nd }}, 3^{\text {rd }}$ and $4^{\text {th }}$ degree haemorrhoids were grouped into two groups, namely Group A (16 cases) who underwent open haemorrhoidectomy and Group B (14 cases) who underwent closed haemorrhoidectomy. Post-operatively the cases were followed up at $7^{\text {th }}$ day, $4^{\text {th }}$ week, $6^{\text {th }}$ week, $3^{\text {rd }}$ month and $6^{\text {th }}$ month.

\section{RESULTS}

The mean age of the patients was $39.6 \pm 4.8$ years, $76.6 \%$ were males. $56.6 \%$ were symptomatic for more than two years; bleeding per anus being predominant. The mean duration of surgery and post-operative analgesic requirement was significantly lesser in Group A. Earlier return of bowel function was observed in Group A. However, post-operative evacuation of bowel was smoother and blood stain was lesser in Group B. Urinary retention during the first 24 hours and hospital stay in Group A was higher but insignificant. In the fourth week, significantly higher incidence of wound infection and serous discharge was observed in Group B, whereas pruritus and hypertrophied granulation tissue formation was significantly higher in Group A. In the sixth week, Group B showed greater incidence of wound healing and Group A showed greater incidence of pruritus and hypertrophied granulation tissue. Healing was completed in all the cases in both the groups in the third month. In the sixth month, skin tags were significantly higher in Group A.

\section{CONCLUSION}

Closed haemorrhoidectomy is better than open haemorrhoidectomy in terms of faster wound healing, smoother bowel clearance and cosmesis, but the operating time, analgesic requirement and infection rates are higher.

\section{KEYWORDS}

Haemorrhoids, Open Haemorrhoidectomy, Closed Haemorrhoidectomy.

HOW TO CITE THIS ARTICLE: Sandalya B. Management of haemorrhoids by open and closed haemorrhoidectomy- A comparative study. J. Evolution Med. Dent. Sci. 2017;6(92):6533-6537, DOI: 10.14260/jemds/2017/1417

\section{BACKGROUND}

The word 'haemorrhoid' is derived from the Greek words'haema' meaning blood, and 'Rhoos' meaning flowing. Because of its wide prevalence and its potential dangerous complications, haemorrhoids have been the subject of study in various countries, and especially in the recent past, several theories have been propagated as to the aetiology of the disease, and the source of bleeding, which constitutes the earliest and the most dramatic symptom of the disease. Right from the period of Hippocrates, the use of cautery for burning the piles masses has been in vogue, and with certain modifications, has been used even in the recent past, though it is now being eclipsed by newer methods.

'Financial or Other Competing Interest': None.

Submission 22-10-2017, Peer Review 17-11-2017,

Acceptance 22-11-2017, Published 04-12-2017.

Corresponding Author:

Dr. Bikash Sandalya,

Assistant Professor

Department of General Surgery,

Silchar Medical College and Hospital.

E-mail: bikashsandilya@gmail.com

DOI: $10.14260 /$ jemds $/ 2017 / 1417$

\section{(c) (i) $(-$}

Haemorrhoidectomy also dates back to history, but the modern concept has been devised by Salmon, modified later by Miles and Milligan. A very recent addition to the treatment of haemorrhoids has been the introduction of stapler haemorrhoidectomy. The simultaneous use of the various modes of treatment over the years, has clearly shown that all the above methods have both their advantages and disadvantages. The maximal benefit to the patient occurs when the treatment mode is chosen after careful consideration of the individual patient- the severity of symptoms, extent of the disease, associated local and general condition, occupation, age, etc.

This study has been taken up to evaluate the effectiveness of open haemorrhoidectomy (Milligan and Morgan) and closed haemorrhoidectomy (Ferguson) in second degree, third degree and fourth degree haemorrhoids.

\section{MATERIALS AND METHODS}

This prospective, non-randomised controlled trial was carried out in the Department of the General Surgery, Silchar Medical College Hospital, the duration of the study being one year, from August 2016 to July 2017. 
Cases of haemorrhoids were selected from among the patients reporting to the surgical out-patient department, as also from different surgical wards. Patients from all age groups, both sexes and engaged in different occupations were included for study.

A detailed history was taken and thorough physical examination including inspection of the perianal region, per rectal digital examination and proctoscopic examination was done in each case. Patients who were suspected, from the history and physical examination, to have other underlying pathology leading to symptomatic haemorrhoids were advised a barium enema, or a sigmoidoscopic examination. All patients were asked to undergo routine pre-operative investigations. The treatment contemplated and the importance of post-treatment followup was explained to the patient. The general pattern of followup visits in this study was at $7^{\text {th }}$ day, $4^{\text {th }}$ week, $6^{\text {th }}$ week, $3^{\text {rd }}$ month and $6^{\text {th }}$ month following the initial treatment. Inclusion criteria were patients with second degree, third degree and fourth degree haemorrhoids. Patients with co-existing anal and perianal conditions like fissures, fistula, inflammatory bowel disease, malignancies, severe systemic disorders to contraindicate operative treatment were excluded from the study.

Haemorrhoidectomy carried out in this study were open haemorrhoidectomy (classical Milligan and Morgan method) and closed haemorrhoidectomy (Ferguson method) depending on whether the overlying mucosal defect was left open or sutured. Initially, 50 patients were considered for participation in the study. Of them, 11 did not fulfil the inclusion criteria and 5 refused to participate. 34 were allotted alternately to the two groups. Group A (17) and Group B (17) irrespective of their age, sex and degree of haemorrhoids. 1 patient in group A and 3 patients in Group B were lost to followup. Therefore, a total of 30 patients, 16 and 14 in Group A (open haemorrhoidectomy) and Group B (closed haemorrhoidectomy) respectively were considered for the study.

All cases were hospitalised at least two days preoperatively. Patients were given a laxative two days before operation and a plain water enema on the previous evening. The patients were put on few residue diets from two days prior to operation.

In the operation theatre, the patients were administered either general or spinal anaesthesia. The patient was then placed in a lithotomy position. After sterile draping was done only the perianal region was done exposed. Antiseptic dressing of the perianal region was followed by per rectal digital examination and the introduction of the lubricated proctoscope.

Following both the procedures, sterile pads were placed over the perianal region and held in position by a T-bandage. Post-operatively, the patients received antibiotics and analgesics. Sedatives were prescribed at bed time on the first post-operative night. Careful attention was paid to prevent retention of urine, the bladder being catheterised, should the patient fail to pass urine on his own.

The rectal tube was removed the next day and the patient was given Betadine/acriflavine hip bath thrice daily henceforth. The patient was put on low residue oral feeding either from the first post-operative evening or the next day. Laxatives were given at bed time by the third post-operative day. Gentle digital rectal dilation was started by the $6^{\text {th }}$ post- operative day. Patients were discharged from the hospital by the $8^{\text {th }}$ post-operative day, with followups on $4^{\text {th }}$ week, $6^{\text {th }}$ week, $3^{\text {rd }}$ month and $6^{\text {th }}$ month following discharge.

Statistical software SPSS version 20.0 was used for statistical analysis. Descriptive statistics was used to calculate the mean and standard deviation. Student's t test for quantitative variables and Fisher's Exact test for qualitative variables were used to compare the outcomes in the two groups. P value $<0.05$ was considered as significant.

\section{RESULTS}

In this study, thirty (30) patients with $2^{\text {nd }}, 3^{\text {rd }}$ and $4^{\text {th }}$ degree haemorrhoids were grouped into two groups, namely Group A (16 cases) and Group B (14 cases). Group A underwent open haemorrhoidectomy and Group B underwent closed haemorrhoidectomy.

The Results of these Two Groups were compared in Terms of the following at Various Points of Time in followup-

- $\quad$ Operating time.

- Primary bleeding.

- Analgesic requirement.

- Urinary retention.

- Normal bowel habit.

- Hospital stay.

- Healing time.

- Wound Infections.

- Serous discharge.

- Wound dehiscence.

- Secondary haemorrhage.

- Pruritus and granuloma formation.

- $\quad$ Skin tags.

- Anal stenosis.

The age of the patients ranged from 25 to 75 years, the youngest being 25 years old while the oldest was 71 years old. The male to female ratio was 3.3:1. It was seen that 17 cases had one symptom or the other for about 2 years, 11 cases for about 1 to 2 years and 2 cases had symptoms for about 7 to 12 months. Among the presenting symptoms, 93\% had bleeding per anus, with or without pain. Other presenting features were mucosal prolapse, pain during defecation, pruritus around the anal region and discharge per anus. There were various associated conditions along with these symptoms like anaemia of varying degrees, fissure-in-ano, fistula-in-ano and chronic bronchitis [Table 1].

It was seen that the Operating time in Group A (35-40 min.) was significantly lesser than in Group B (45-50 min.). Analgesic requirement was significantly lower in Group A [Table 2].

Post-operatively the cases were followed up at 7 days, $4^{\text {th }}$ week, $6^{\text {th }}$ week, $3^{\text {rd }}$ month and $6^{\text {th }}$ month.

3 cases in Group A and 2 cases in Group B had urinary retention during the first 24 hours, the difference being insignificant. Post-operative evacuation of bowel was earlier in Group A, but it was smoother and blood stain was lesser in Group B compared to group A. Hospital stay of Group A cases was more by about 1 - 2 days, the difference was insignificant. Primary haemorrhage, wound healing, wound infection, wound dehiscence, secondary haemorrhage, pruritus and 
granuloma formation, skin tags and anal stenosis were not seen during the $1^{\text {st }}$ week in both the groups. [Table 3].

\section{In the $4^{\text {th }}$ Week,}

Wound infection and serous discharge was found to be significantly higher in Group B. Wound healing was not completed in a significant number of the cases in both groups. Pruritus and granuloma formation was seen in 6 cases of Group A and 1 case of Group B, being significantly higher in Group A. Wound dehiscence was seen in 2 cases of Group B. [Table 4].

\section{In the $6^{\text {th }}$ Week,}

No wound infections and serous discharge were seen. Healing was faster in Group B. Healthy granulation tissue could be seen in the unhealed cases of both the groups. Pruritus and hypertrophic granulation tissue persisted in 2 cases in Group A. [Table 5]

\section{In the $3^{\text {rd }}$ Month,}

Wound healing was complete in both the groups. 2 cases of wound dehiscence healed by secondary intention. No cases in both groups had pruritus and granuloma formation. [Table 6].

\section{In the $6^{\text {th }}$ Month,}

The two wound dehiscence cases healed by secondary intention but one case developed anal stenosis subsequently. This patient was suffering from $4^{\text {th }}$ degree internal haemorrhoids with 3 circumferential external haemorrhoids and wound dehiscence and wound infection was seen post-operatively. 6 cases in Group A and 1 case in Group B had skin tags, which were not distressing to the patients. [Table 7].

Thus, the inference that could be drawn from the study was that closed haemorrhoidectomy had faster wound healing than open haemorrhoidectomy. But the risk of wound dehiscence is inherent in closed haemorrhoidectomy especially when rapidly absorbable suture like catgut is used for closure in an area of potential source of infection like anal canal. Wound infection of low grade was seen in few cases of Group B; however, these did not increase the morbidity. Post-operative skin tags were higher in Group A.

\begin{tabular}{|c|c|}
\hline Demographic Details & Range/ Frequency \\
\hline Age (years) & $39.6 \pm 4.8$ \\
Sex & $23(76.6 \%)$ \\
Male & $7(23.3 \%)$ \\
Female & $17(56.6 \%)$ \\
Duration of symptoms & $11(36.6 \%)$ \\
$>2$ years & $2(6.6 \%)$ \\
$1-2$ years & \\
6 months - 1 year & $17(56.6 \%)$ \\
Clinical features & $11(36.6 \%)$ \\
Only bleeding & $5(16.6 \%)$ \\
Bleeding with pain & $12(40 \%)$ \\
Prolapse & $5(16.6 \%)$ \\
Pain & $5(16.6 \%)$ \\
Pruritus &
\end{tabular}

\begin{tabular}{|c|c|}
\hline in-ano & \\
Associated conditions & $10(33.3 \%)$ \\
Anaemia & $6(20 \%)$ \\
Fissure-in-ano & $5(16.6 \%)$ \\
Fistula-in-ano & $1(3.3 \%)$ \\
Enlarged prostate & $2(6.6 \%)$ \\
Chronic bronchitis & Table 1. Baseline Characteristics of All Cases \\
\hline
\end{tabular}

\begin{tabular}{|c|c|c|c|}
\hline Parameters & Group A & Group B & P value* \\
\hline $\begin{array}{c}\text { Mean Operating } \\
\text { time (minutes) } \\
\text { Mean Analgesic } \\
\text { requirement } \\
\text { (hours) }\end{array}$ & $30.2 \pm 2.8$ & $55.4 \pm 1.9$ & $<0.05$ \\
\hline \multicolumn{3}{|c|}{ Table 2. Comparison of Duration of Surgery and } \\
Analgesia Requirement in the Two Groups \\
\hline
\end{tabular}

${ }^{*} \mathrm{P}$ value is significant

\begin{tabular}{|c|c|c|c|}
\hline Outcome & Group A & Group B & P value* \\
\hline $\begin{array}{c}\text { Establishment of } \\
\text { normal bowel habit } \\
\text { (hours) }\end{array}$ & $48-72$ & $>72$ & \\
\hline $\begin{array}{l}\text { Urinary retention in } \\
\text { first } 24 \text { hours }\end{array}$ & $3(18.8 \%)$ & $2(14.3 \%)$ & $>0.05$ \\
\hline $\begin{array}{c}\text { Primary bleeding } \\
\text { within } 24 \text { hours }\end{array}$ & 0 & 0 & \\
\hline $\begin{array}{l}\text { Duration of hospital } \\
\text { stay (days) }\end{array}$ & $7-8$ & $6-7$ & $>0.05$ \\
\hline Wound healing & 0 & 0 & \\
\hline Wound infection & 0 & 0 & \\
\hline Wound dehiscence & Not applicable & 0 & \\
\hline Serous discharge & \begin{tabular}{l|l}
0 & \\
\end{tabular} & 0 & \\
\hline $\begin{array}{c}\text { Secondary } \\
\text { haemorrhage }\end{array}$ & 0 & 0 & \\
\hline $\begin{array}{c}\text { Pruritus and } \\
\text { hypertrophic } \\
\text { granulation tissue }\end{array}$ & 0 & 0 & \\
\hline Skin tags & 0 & 0 & \\
\hline Anal stenosis & \begin{tabular}{|l|l|}
0 & \\
\end{tabular} & 0 & \\
\hline \multicolumn{4}{|c|}{ Table 3. Comparison of Outcome in the First Week } \\
\hline
\end{tabular}

${ }^{*} \mathrm{P}$ value is insignificant.

\begin{tabular}{|c|c|c|c|}
\hline Outcome & Group A & Group B & P value* \\
\hline Wound healing & Not healed & $9(63.1 \%)$ & \\
\hline Wound infection & $1(6.25 \%)$ & $5(35.7 \%)$ & $<0.05$ \\
\hline Wound dehiscence & Not applicable & $2(14.3 \%)$ & \\
\hline Serous discharge & $1(6.25 \%)$ & $5(35.7 \%)$ & $<0.05$ \\
\hline $\begin{array}{c}\text { Secondary } \\
\text { haemorrhage }\end{array}$ & 0 & 0 & \\
\hline $\begin{array}{l}\text { Pruritus and } \\
\text { hypertrophic } \\
\text { granulation } \\
\text { tissue }\end{array}$ & $6(37.5 \%)$ & $1(7.14 \%)$ & $<0.05$ \\
\hline Skin tags & 0 & 0 & \\
\hline Anal stenosis & 0 & 0 & \\
\hline \multicolumn{4}{|c|}{ Table 4. Comparison of Outcome in the Fourth Week } \\
\hline
\end{tabular}

${ }^{*} \mathrm{P}$ value is significant. 


\begin{tabular}{|c|c|c|c|}
\hline Outcome & Group A & Group B & P value \\
\hline Wound healing & $12(75 \%)$ & $12(85.7 \%)$ & $>0.05$ \\
\hline Wound infection & 0 & 0 & \\
\hline Wound dehiscence & $\begin{array}{c}\text { Not } \\
\text { applicable }\end{array}$ & healed & \\
\hline Serous discharge & 0 & 0 & \\
\hline $\begin{array}{c}\text { Pruritus and } \\
\text { hypertrophic } \\
\text { granulation tissue }\end{array}$ & $2(12.5 \%)$ & 0 & \\
\hline Skin tags & 0 & 0 & \\
\hline Anal stenosis & 0 & 0 & \\
\hline
\end{tabular}

Table 5. Comparison of Outcome in the Sixth Wee

${ }^{*} \mathrm{P}$ value is insignificant

\begin{tabular}{|c|c|c|}
\hline Outcome & Group A & Group B \\
\hline Wound healing & $16(100 \%)$ & $14(100 \%)$ \\
\hline Wound infection & 0 & 0 \\
\hline Wound dehiscence & Not applicable & healed \\
\hline Serous discharge & 0 & 0 \\
\hline Secondary haemorrhage & 0 & 0 \\
\hline $\begin{array}{c}\text { Pruritus and hypertrophic } \\
\text { granulation tissue }\end{array}$ & 0 & 0 \\
\hline Skin tags & 0 & 0 \\
\hline Anal stenosis & 0 & 0 \\
\hline
\end{tabular}

Table 6. Comparison of Outcome in the Third Mon

\begin{tabular}{|c|c|c|c|}
\hline Outcome & Group A & Group B & P value* \\
\hline Wound healing & $16(100 \%)$ & $14(100 \%)$ & \\
\hline Wound infection & 0 & 0 & \\
\hline Wound dehiscence & Not applicable & healed & \\
\hline Serous discharge & 0 & 0 & \\
\hline $\begin{array}{c}\text { Secondary } \\
\text { haemorrhage }\end{array}$ & 0 & 0 & \\
\hline $\begin{array}{c}\text { Pruritus and } \\
\text { hypertrophic } \\
\text { granulation tissue }\end{array}$ & 0 & 0 & \\
\hline Skin tags & $6(37.5 \%)$ & $1(7.14 \%)$ & $<0.05$ \\
\hline Anal stenosis & 0 & $1(7.14 \%)$ & \\
\hline \multicolumn{2}{|c|}{ Table 7. Comparison of Outcome in the Sixth Mon }
\end{tabular}

${ }^{*} \mathrm{P}$ value is significant

\section{DISCUSSION}

In the present series, the maximum number of cases were between 31 to 40 years (32.14\%) followed closely by the group between 21 to 30 years (30.35\%). Thus, nearly $62.49 \%$ of the cases belonged to the age group between 21 and 40 years. The maximum age of haemorrhoidal disease was found to be between 30 to 50 years in one study.[1] The present series had $77 \%$ male patients and $23 \%$ female patients. Most of the published series put the incidence in males to be much higher than in females.[1,2] Bleeding was the presenting symptom in $93 \%$ in the present series.

In the present study, the operating time in Group A was found to be significantly lesser than Group B which is comparable with other studies.[1,2,3,4,5] The post-operative analgesics requirement in Group $\mathrm{A}$ was found to be significantly lesser than Group B which is comparable with other studies. $[1,2,6,7]$ However, in some other studies, $[3,4,8]$ postoperative pain was lesser in Group B. In the present study, the post-operative urinary retention in Group A was higher compared to Group B, the difference being insignificant, which is comparable with other studies.[1,9,10] Early establishment of normal bowel habit was observed in open haemorrhoidectomy in the present study, which is comparable with another study.[9] In the present study, none of the cases had primary haemorrhage in both the groups. However, in one study,[1] higher incidence of primary haemorrhage was observed in Group A. The post-operative hospital stay period was lesser in Group B, but the difference was insignificant as was also observed in a study.[2,8,9] In the present study, the wound healing time was faster in Group B which was also noted in several studies.[1,2,3,7,8,11,12,13] The post-operative wound infection was significantly high in Group B in the present study and is comparable with other studies. $[1,5,9,12,14]$

In the present study, $14.3 \%$ cases had wound dehiscence in Group B. Both these cases had wound infections followed by wound dehiscence. Similar results were observed in some studies. $[5,9,12,13]$ The post-operative serous discharge was significantly high in Group B in the present study and is similar to findings in other studies.[9,13] In the present study, the post-operative pruritus and granuloma formation was found to be significantly higher in Group A and is comparable with another study.[9] The post-operative skin tag formation was found to be significantly high in Group A in the present study which was also observed in another study.[12]

\section{CONCLUSION}

Closed haemorrhoidectomy is better than open haemorrhoidectomy in terms of faster wound healing, relative freedom of morbidity, first bowel evacuation was pain free and without any blood stain and with lower incidence of pruritus and hypertrophied granulation tissue formation. Cosmetically closed haemorrhoidectomy is better as skin tags are also lesser in post-operative period. Open haemorrhoidectomy needed lesser mean operating time and analgesic in the post-operative period. As the wound was open, infections were better contained in open haemorrhoidectomy but this was not a threat in closed cases either.

\section{REFERENCES}

[1] Shaikh AR, Dalwani AG, Soomro N. An evaluation of Milligan-Morgan and Ferguson procedures for haemorrhoidectomy at Liaquat university hospital, Jamshoro, Hyderabad, Pakistan. Pak J Med Sci 2013;29(1):122-7.

[2] Sharma BK, Bakliwal A, Solanki MK. A comparative study of open (Milligan-Morgan) versus closed (Ferguson) hemorrhoidectomy-our experience. Journal of Dental and Medical Sciences 2016;15(4):2730.

[3] Bhatti MI, Sajid MS, Baig MK. Milligan-Morgan (open) versus Ferguson haemorrhoidectomy (closed): a systematic review and meta-analysis of published randomized, controlled trials. World J Surg 2016;40(6):1509-19.

[4] Pokharel N, Chhetri RK, Malla B, et al. Haemorrhoidectomy: Ferguson's (closed) vs MilliganMorgan's technique (open). Nepal Med Coll J 2009;11(2):136-7.

[5] Gencosmanoglu R, Sad 0, Koc D, et al. Hemorrhoidectomy: open or closed technique? A prospective, randomized clinical trial. Dis Colon Rectum 2002;45(1):70-5. 
[6] Basher M, Nadeem T, Iqbal J, et al. Ileostomy in typhoid perforation. Ann King Adward Med Coll 2003;9:1-3.

[7] You SY, Kim SH, Chung CS, et al. Open vs. closed haemorrhoidectomy. Dis Colon Rectum 2005;48(1):108-13.

[8] Borse H, Dhake S. A comparative study of open (Milligan-Morgan) versus closed (Ferguson) hemorrhoidectomy. MVP Journal of Medical Sciences 2016;3(1).

[9] Rafiq K, Scott PD. Closed vs. open haemorrhoidectomy little to choose between two techniques. Ann King Edward Med Coll 2001;7(1):6-7.

[10] Uba AF, lhezue CH, Obekpa PO, et al. Open haemorrhoidectomy revisited. Niger J Med 2001;10(4):185-8.
[11] Arroyo A, Pérez F, Miranda E, et al. Open versus closed day-case haemorrhoidectomy: is there any difference? Results of a prospective randomised study. Int J Colorectal Dis 2004;19(4):370-3.

[12] Uba AF, Obekpa PO, Ardill W. Open versus closed haemorrhoidectomy. Niqer Postgrad Med J 2004;11(2):79-83.

[13] Khubchandani IT. Randomized controlled trial of open and closed haemorrhoidectomy. Br J Surg 1998;85(5):716-7.

[14] Arbman G, Krook H, Haapaniemi S. Closed vs. open hemorrhoidectomy--is there any difference? Dis Colon Rectum 2000;43(1):31-4. 